\title{
CIRCULATING miR-210 AND miR-1246 AS POTENTIAL BIOMARKERS FOR DIFFERENTIATING HEPATOCELLULAR CARCINOMA FROM METASTATIC TUMORS IN THE LIVER
}

\author{
miR-210 I miR-1246 U CIRKULACIJI KAO POTENCIJALNI BIOMERKERI ZA DIFERENCIRANJE \\ HEPATOCELULARNOG KARCINOMA KOD METASTATSKIH TUMORA JETRE
}

\author{
Emad K. Ahmed ${ }^{1}$, Shaimaa A. Fahmy ${ }^{2}$, Heba Effat ${ }^{2}$, Abdel Hady Abdel Wahab ${ }^{2}$ \\ ${ }^{1}$ Department of Biochemistry, Faculty of Science, Ain Shams University, Cairo, Egypt \\ ${ }^{2}$ Department of Cancer Biology, National Cancer Institute, Cairo University, Egypt
}

\section{Summary}

Background: To date few reports have pointed out the role of circulating miRNAs in discriminating metastatic liver tumors from primary hepatocellular (HCC) tumors. Such discrimination will have significant therapeutic and prognostic implications. The purpose of this study was to evaluate the potential value of a panel of HCC-related circulating miRNAs (miR-142, miR-182, miR-200a, mir-210, miR-211, miR-302b, miR-324, miR-338, miR-340 and miR-1246) as noninvasive biomarkers for discriminating primary HCC from metastatic tumors in the liver.

Methods: The expression level of the selected miRNAs was quantified by quantitative real time PCR in 33 patients with HCC, 22 patients with metastatic tumors in the liver, and 30 healthy volunteers as control. Mann-Whitney $U$ test was used to evaluate the difference in miRNAs expression between primary and metastatic liver tumors and to study the associations between their relative expression levels and the clinicopathological factors. Receiver operating characteristic curve was used to evaluate the diagnostic value of the individual miRNAs.

Results: Statistical analyses revealed a differential expression in the level of serum miR-210 and miR-1246 between the two groups of patients. The sensitivity and specificity of miR-210, for differentiating HCC from metastatic malignancies in the liver were found to be $73.7 \%$ and $64.28 \%$, respectively. Whilst, of miR-1246 were $72.2 \%$ and $67.8 \%$, respectively. In addition, the differential expression of the two miRNAs was also found to be associated with clinicopathological parameters in the two studied groups.

\section{Kratak sadržaj}

Uvod: Danas ima nekoliko podataka o ulozi cirkulišućeg miRNK za razlikovanje metastskih tumora jetre od primarnih hepatocelularnih tumora (HCC). Takva prepoznavanje imalo bi značajan terapeutski i prognostički značaj. Svrha ovog izučavanja je bila da se proceni potencijalna vrednost panela miRNK, (miR-142, miR-182, miR200a, mir-210, miR-211, miR-302b, mR-324, mR-338, mR-340 i miR-1246) koji se nalaze u cirukulaciji, a u vezi su sa HCC kao neinvanzivnih biomarkera za razlikovanje primarnog HCC od metastatskih karcinoma jetre.

Metode: Ekspresija nivoa selektovanih miRNK je određena primenom kvantitativne real time PCR u 33 pacijenta sa HCC, 22 pacijenta sa metastatskim tumorima jetre i 30 zdravih osoba kao kontrolne volonterske grupe. MannWhitney $U$ test je korišćen za procenu razlika u miRNK ekspresiji između primarnih i metastskih tumora jetre kao i za procenu između nivoa njihove relativne ekspresije i kliničkopatioloških faktora. ROC kriva je korišćena za procenu dijagnostičke vrednosti pojedinih miRNK.

Rezultati: Statistička analiza je ukazala na diferencijalnu ekspresiju nivoa serumske miR-210 i miR-1246 između dve grupe pacijenata. Osetljivost i specifičnost miR-210 za razlikovanje HCC kod metastatskog maligniteta jetre nađeno je da iznosi $72,7 \%$ odnosno $64,28 \%$, dok je u slučaju miR1246 iznosila 72,2\% odnosno 67,8\%. Osim toga nađena je diferencijalna ekspresija dve miRNK u vezi sa kliničko-patološkim parametrima u obe proučavane grupe.

\footnotetext{
Address for correspondence:

Abdel Hady A. Abdel Wahab, PhD

Professor and Former Chair of Cancer Biology Department, National Cancer Institute, Cairo University

Kasr El Eini Street, Fom El Khalig Cairo 11796, Egypt

Telephone: +202 - 1005849055

Fax: +202 - 23644720
} 
Conclusions: Serum miR-210 and miR-1246 have some diagnostic value for discriminating patients with metastatic tumors to patients with primary $\mathrm{HCC}$

Keywords: circulating miRNAs; biomarkers; HCC; liver metastasis

\section{Introduction}

Hepatocellular carcinoma (HCC) is one of the most aggressive human malignancies worldwide, accounting for $90 \%$ of primary liver cancers (1). Despite the advances in HCC treatment, the high frequencies of postsurgical recurrence and metastasis are the main causes of the dismal therapeutic outcome of HCC (2). One of the main obstacles in HCC therapy is to differentiate hepatocellular carcinoma from metastatic tumors in the liver. This distinction may not be easy because of the high degree of similarity between hepatocellular carcinoma and metastatic liver cancers, especially adenocarcinoma, on the level of morphology and the immunoexpressed markers (3). At the present time, identification of the origin of these metastases and their differential diagnosis from primary $\mathrm{HCC}$ requires precise pathological investigation using a panel of immunostains (4). In addition, the use of advanced imaging techniques and their correlation with the clinical state of the patient is also needed. In most of the cases, these previous methodologies have failed in the detection of the primary site of cancer (5) and in turn, misled the choice of the best treatment regime (6) and hence, poor prognosis in the majority of patients (7). Therefore, searching for novel diagnostic markers for hepatic cancers will improve both the diagnosis and treatment.

MicroRNAs (miRNAs) are special class of small non-coding RNAs that play critical roles in the regulation of gene expression. They are characterized by their remarkable tissue specificity and are nearly involved in the regulation of all aspects of cellular activity including metabolism, cell proliferation, apoptosis, differentiation, cellular response to viral infection, and tumorigenesis (8). Several studies have pointed out the value of miRNAs as potential markers for tissue classification and identification (9-11). In addition, circulating miRNAs which are protected from RNAase-mediated degradation in body fluids have been emerged as candidates of non-invasive biomarkers in the diagnosis of many diseases, including liver diseases (12-14).

Recently, Tan $Y$ et al. (15) have identified a panel of serum miRNAs as biomarkers to be used in the diagnosis of hepatitis B virus-related HCC, as well as, in differentiating HCC patients from healthy and cirrhotic patients. Moreover, have identified miRNAs signature that significantly predicted metastasis-free $\mathrm{HCC}$ and HCC from venous metastasis, as well as, tumor recurrence. A related study has used miRNA
Zaključak: Serumska miR-210 i miR-1246 imale su izvesnu dijagnostički značajnu vrednost za metastatske tumore pacijenata sa primarnim HCC.

Ključne reči: cirkulišuća miRNK, HCC, metastaza jetre

expression profile in the segregation of non-tumorous livers from primary HCC and venous metastasis (16). Using miRNA expression profiling, it was also possible to differentiate primary from metastasized brain tumors (17).

The goal of the present study was to explore the potential use of serum miRNAs as biomarkers for discriminating Egyptian patients with primary HCC from patients with metastatic tumors in the liver. To fulfill this, a panel of cancer-associated miRNAs namely miRNA-142, 182, 200a, 210, 211, 302b, 324, 338, 340 , and 1246, was chosen on the basis of their reported relevance to $\mathrm{HCC}(18-24)$ and were detected by qRT-PCR among 33 primary HCC patients, 22 patients with metastatic liver tumors of different origins, and 30 healthy volunteers used as controls.

\section{Materials and Methods}

\section{Patients and samples}

This study was performed according to the guidelines for the use of human subjects' materials according to the 'Declaration of Helsinki' and approved by the Institutional Review Board. A written informed consent was obtained from all the participants involved. Serum samples were obtained from 33 patients with primary hepatocellular carcinoma, 22 patients with metastatic tumors in the liver, in addition to, 30 healthy volunteers, during the period 2013-2014. The HCC patients were diagnosed by abdominal ultrasonography, triphasic CT abdomen, serum alfa-fetoprotein (AFP), and were confirmed histopathologically with no evidence of local invasion or distant metastasis. The control group had no clinical or biochemical evidence of liver disease or known medical illness at recruitment and with normal abdominal ultra-sonography. All controls were negative for HBV and HCV infection as evidenced by negative serological markers and negative PCR for HBV and HCV. The relevant clinico-pathological characteristics of the studied subjects are shown in Table I. Five $\mathrm{ml}$ blood samples were collected from patients and controls for serum separation, and all the samples were processed on the same day within few hours of collection.

\section{Quantitative RT-PCR for miRNA expression}

Total RNA including miRNA was extracted from serum samples using miRNeasy Mini kit (Qiagen, 
Table I Demographic and laboratory data of the participants.

\begin{tabular}{|c|c|c|c|}
\hline Clinical variable & Primary HCC $(n=33)$ & Metastatic HCC $(n=22)$ & Healthy controls $(n=30)$ \\
\hline \multicolumn{4}{|l|}{ Age (Years) no. (\%) } \\
\hline$\leq 60 y$ & $19(57.6)$ & $10(45.5)$ & $20(66.7)$ \\
\hline$>60 y$ & $14(42.4)$ & $12(54.5)$ & $10(33.3)$ \\
\hline \multicolumn{4}{|l|}{ Gender, no. (\%) } \\
\hline Male & $24(72.7)$ & $12(54.5)$ & $18(60)$ \\
\hline Female & $9(27.2)$ & $10(45.4)$ & $12(40)$ \\
\hline \multicolumn{4}{|l|}{$\mathrm{HCV}$, no. (\%) } \\
\hline Yes & $24(72.7)$ & $7(31.8)$ & $0(0)$ \\
\hline No & $9(27.2)$ & $15(68.1)$ & $30(100)$ \\
\hline \multicolumn{4}{|l|}{ Cirrhosis, no. (\%) } \\
\hline Yes & $15(45.4)$ & $10(45.4)$ & $0(0)$ \\
\hline No & $18(54.5)$ & $12(54.5)$ & $30(100)$ \\
\hline \multicolumn{4}{|l|}{ Laboratory values } \\
\hline \multicolumn{4}{|c|}{ Median (Interquartile) } \\
\hline $\mathrm{AFP}(\mathrm{ng} / \mathrm{mL})$ & $180(1-1413)$ & $23(1-306)$ & $4.9(3-8)$ \\
\hline $\mathrm{ALT}(\mathrm{U} / \mathrm{L})$ & $60(10-609)$ & $21.60(9-67)$ & $23(17-32)$ \\
\hline AST (U/L) & $51(15-185)$ & $31(8-105)$ & $26(0-33)$ \\
\hline \multicolumn{4}{|l|}{ Origin(n) } \\
\hline Liver & 33 & -- & --- \\
\hline Adenocarcinoma & --- & 13 & --- \\
\hline Bladder & --- & 1 & --- \\
\hline Colon & --- & 1 & --- \\
\hline Pancreas & --- & 1 & --- \\
\hline Ovary & --- & 1 & --- \\
\hline Unknown & --- & 5 & --- \\
\hline
\end{tabular}

Germany). Frozen serum samples were incubated at $37{ }^{\circ} \mathrm{C}$ in a water bath until they were completely thawed, then $200 \mu \mathrm{L}$ of serum were added to 1000 $\mu$ l of Qiazol lysis reagent. The extraction was performed according to the instruction manual of the manufacture. cDNA was synthesized from the isolated RNA using miScript II RT kit (Qiagen) according to the manufacturer instructions. The relative expression of miRNAs was quantified by miScript SYBER Green PCR kit (Qiagen), which includes miScript universal primer and quantiTect SYBER Green PCR master mix. The reactions were performed in 384 well plates with $10 \mu \mathrm{L}$ total volume/well and contained $1 \mathrm{X}$ SYBER green master mix, $200 \mathrm{nmol} / \mathrm{L}$ forward primer (miRNA specific primer) and $200 \mathrm{nmol} / \mathrm{L}$ universal primer, using $3 \mathrm{ng}$ cDNA/well. The conditions included initial denaturation at $95{ }^{\circ} \mathrm{C}$ for $15 \mathrm{~min}$., followed by 40 cycles of $94{ }^{\circ} \mathrm{C}$ for $15 \mathrm{~s}, 55^{\circ} \mathrm{C}$ for $30 \mathrm{~s}$, and $72{ }^{\circ} \mathrm{C}$ for $30 \mathrm{~s}$. All the samples were performed in duplicates on ViiA 7 real time PCR system (Applied Biosystem, Foster city, CA, USA). miR-16 was used as an endogenous control $(25,26)$. The relative gene expression analysis of the target miRNAs was performed using the delta-delta-Ct method as described previously (27).

\section{Statistical analysis}

Statistical analysis was performed using SPSS 20 software (SPSS, Inc., Chicago, IL, USA). Results of miRNAs expression were analyzed and were found to demonstrate an abnormal distribution. All miRNA expression data are shown as the median and interquartile range (IQR). The nonparametric Mann-Whitney $U$ test was used to study the different associations between the relative expression levels of circulating miRNA and the clinic-pathological factors as well as to evaluate the differences in the miRNA expression between primary HCC and metastatic liver tumor samples. Diagnostic values for individual miRNAs were determined by calculating the area under the receiver operating characteristic (ROC) curves. $P<0.05$ was considered statistically significant.

\section{Results}

\section{Patients' characteristics}

A total of 85 participants including 33 primary HCC patients, 22 patients with metastatic liver tumors, and 30 normal volunteer were recruited into this study. The characteristics of the study subjects, as well as, the 
Table II Expression levels of the studied miRNAs.

\begin{tabular}{|l|c|c|c|}
\hline miRNA & Primary HCC $(\mathrm{n}=33)$ & Metastatic H CC $(\mathrm{n}=22)$ & $\mathrm{p}$ value \\
\hline miR-142 & $0.215(0.074-2.526)$ & $0.360(0.068-0.939)$ & 0.902 \\
\hline miR-182 & $0.212(0.090-0.701)$ & $0.138(0.054-0.546)$ & 0.605 \\
\hline miR-200a & $0.321(0.049-1.175)$ & $0.244(0.057-1.954)$ & 0.983 \\
\hline miR-210 & $0.233(0.029-5.768)$ & $2.008(0.799-8.417)$ & $0.03^{*}$ \\
\hline miR-211 & $0.341(0.096-5.168)$ & $1.355(0.192-4.467)$ & 0.405 \\
\hline miR-302b & $0.407(0.030-4.086)$ & $0.437(0.047-1.041)$ & 0.776 \\
\hline miR-324 & $0.606(0.066-9.755)$ & $1.437(0.153-11.007)$ & 0.480 \\
\hline miR-338 & $0.255(0.031-1.302)$ & $0.208(0.053-2.268)$ & 0.562 \\
\hline miR-340 & $0.425(0.335-1.253)$ & $0.282(0.038-0.796)$ & 0.396 \\
\hline miR-1246 & $2.409(0.063-168.764)$ & $42.839(4.674-125.990)$ & $0.048 *$ \\
\hline
\end{tabular}

Results are expressed as Median fold change (Interquartile range: 25-75\%)

*significant (Significance level at $\mathrm{P}<0.05$ )

subjects' data including Laboratory values are summarized in Table I. The age distribution between patients with either primary or metastatic liver tumors was almost similar; however, the percentage of male patients was higher $(72.7 \%)$ in primary HCC group than in the metastatic liver tumors group (54.5\%).

\section{Serum miR-210 and miR-1246 differential} expression in the two studied groups:

Using qRT-PCR, the expression levels of 10 miRNAs in the sera of patients with primary and metastatic liver tumors were measured (Table II). Our data showed that of the 10 studied miRNAs, only miR-210 and miR-1246 were significantly deregulated between the two patients' groups. The expression level of miR-1246, as well as, miR-210 were significantly higher in metastatic liver tumors compared to patients with primary HCC patients $(P<0.05)$.

miR-210 and miR-1246 expression levels and clinicopathological characteristics

To further investigate the effect of the clinicopathological factors on the differential expression of miR-210 and miR-1246 between the primary and metastatic HCC patients, patients' groups were subdivided into subgroups according to the clinicopathological factors, as shown in Table III. The expression levels of miR-210 and miR-1246 were then compared between the two groups using the non-parametric Mann-Whitney $U$ test. Results revealed the presence of significant association between miR-210 differential expression and age ( $>60$ years), as well as, the presence of HCV infection. In addition, the expression of miR-210 was also significantly associated with the level of serum ALT ( $\leq 40 \mathrm{U} / \mathrm{L})$. On the other hand, miR-1246 differential expression was observed among females, patients $\leq 60$ years old, as well as patients with cirrhosis and low level of serum $\operatorname{AFP}(\leq 200 \mathrm{ng} / \mathrm{mL})$.

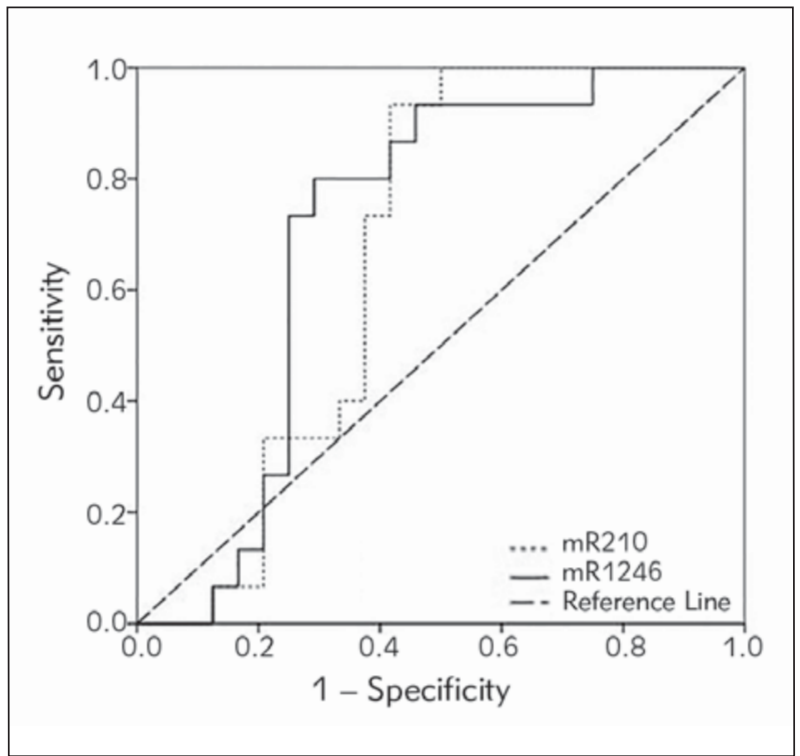

Figure 1 The ROC curve of miR-210 and miR-1246 for discriminating hepatocellular carcinoma from metastatic liver tumors. The AUC of miR-210 was $0.67(p=0.073)$ at a cut off value of 0.916 , the sensitivity was $73.68 \%$ and the specificity was $64.28 \%$. The AUC of miR-1246 was 0.708 $(p=0.03)$ at a cut off value of 9.951 , the sensitivity was $72.2 \%$ and the specificity was $67.8 \%$.

\section{Differential Diagnostic potential of circulating} miR-210 and miR-1246

ROC curves were used to study the potential of serum miR-210 and miR-1246 to discriminate patients with primary $\mathrm{HCC}$ from patients with metastatic liver tumors. The ROC curve for serum miR-210 expression levels had an AUC of 0.67, with $73.7 \%$ sensitivity and $64.28 \%$ specificity, at a cutoff value of 0.92 (fold change). The ROC curve for serum miR-1246 expression levels had an AUC of 0.708 , with $72.2 \%$ sensitivity and $67.8 \%$ specificity, at a cutoff value of 9.95 (fold change) (Figure 1). SPSS 
Table III Association of miR-210 and miR-1246 expression levels with clinicopathological factors.

\begin{tabular}{|c|c|c|c|}
\hline Parameter & Primary HCC & Metastatic HCC & Mann-Whitney P-value \\
\hline \multicolumn{4}{|l|}{ Age (year) } \\
\hline \multicolumn{4}{|l|}{ miR-210 } \\
\hline$\leq 60$ & $0.880(0.134-10.045)$ & $1.388(0.681-5.997)$ & 0.531 \\
\hline$\leq 60$ & $0.056(0.027-7.131)$ & $3.691(1.007-10.391)$ & $0.018^{*}$ \\
\hline \multicolumn{4}{|l|}{ miR-1246 } \\
\hline$\leq 60$ & $1.261(0.129-10.429)$ & 93.441(29.010-724.479) & $0.013^{*}$ \\
\hline$>60$ & 5.704(0.015-213.449) & 19.041(3.230-88.945) & 0.951 \\
\hline \multicolumn{4}{|l|}{ Gender } \\
\hline \multicolumn{4}{|l|}{ miR-210 } \\
\hline Male & $0.324(0.033-7.131)$ & 1.480(0.681-7.726) & 0.159 \\
\hline Female & $0.056(0.038-28.616)$ & $3.691(1.519-22.112)$ & 0.165 \\
\hline \multicolumn{4}{|l|}{ miR-1246 } \\
\hline Male & $5.544(0.067-213.449)$ & $81.281(18.642-165.666)$ & 0.147 \\
\hline Female & $0.191(0.029-0.861)$ & 12.811(3.230-63.807) & $0.007 *$ \\
\hline \multicolumn{4}{|l|}{$\mathrm{HCV}$} \\
\hline \multicolumn{4}{|l|}{ miR-210 } \\
\hline Yes & $0.324(0.028-5.840)$ & $8.140(2.834-22.112)$ & $0.024^{*}$ \\
\hline No & $0.143(0.081-32.794)$ & $1.007(0.681-5.977)$ & 0.346 \\
\hline \multicolumn{4}{|l|}{ miR-1246 } \\
\hline Yes & 1.654(0.030-213.449) & $12.811(3.230-76.405)$ & 0.341 \\
\hline No & 2.980(0.109-10.509) & 68.683(18.642-165.666) & 0.075 \\
\hline \multicolumn{4}{|l|}{ Cirrhosis } \\
\hline \multicolumn{4}{|l|}{ miR-210 } \\
\hline Yes & $0.125(0.051-41.369)$ & $0.930(0.733-6.371)$ & 0.206 \\
\hline No & $0.336(0.030-5.697)$ & $2.849(1.208-7.689)$ & 0.139 \\
\hline \multicolumn{4}{|l|}{ miR-1246 } \\
\hline Yes & $0.201(0.030-6.371)$ & 192.552(82.646-6.371) & $0.032 *$ \\
\hline No & $2.095(0.238-1232.561)$ & 15.926(2.700-54.366) & 0.488 \\
\hline \multicolumn{4}{|c|}{ AFP $(\mathrm{ng} / \mathrm{mL})$} \\
\hline \multicolumn{4}{|c|}{ miR-210 } \\
\hline$\leq 200$ & $0.134(0.045-7.714)$ & 2.008(0.799-8.417) & 0.069 \\
\hline$>200$ & $0.330(0.032-8.911)$ & $0.952(0.182)$ & \# \\
\hline \multicolumn{4}{|l|}{ miR-1246 } \\
\hline$\leq 200$ & $1.057(0.029-8.106)$ & 61.018(12.811-126.368) & $0.029 *$ \\
\hline$>200$ & $4.262(0.147-1071.488)$ & $17.446(2.170)$ & $\#$ \\
\hline \multicolumn{4}{|l|}{$\mathrm{ALT}(\mathrm{U} / \mathrm{L})$} \\
\hline \multicolumn{4}{|l|}{ miR-210 } \\
\hline$\leq 40$ & $0.083(0.034-3.823)$ & $2.008(1.062-7.456)$ & $0.014^{*}$ \\
\hline$>40$ & $0.608(0.057-14.237)$ & $8.417(0.711)$ & $\#$ \\
\hline \multicolumn{4}{|l|}{ miR-1246 } \\
\hline$\leq 40$ & $0.264(0.028-1.556)$ & $76.347(34.409)$ & \# \\
\hline$>40$ & $6.397(0.193-561.932)$ & $51.268(4.290)$ & \# \\
\hline \multicolumn{4}{|l|}{ AST (U/L) } \\
\hline \multicolumn{4}{|l|}{ miR-210 } \\
\hline$\leq 40$ & $0.051(0.028-5.448)$ & $3.730(0.937-6.963)$ & 0.160 \\
\hline$>40$ & $0.336(0.125-14.196)$ & $5.074(0.974-15.264)$ & 0.105 \\
\hline \multicolumn{4}{|l|}{ miR-1246 } \\
\hline$\leq 40$ & $1.261(0.021-63.177)$ & 47.714(12.811-109.652) & 0.088 \\
\hline$>40$ & 5.544(0.067-678.09) & $88.945(39.523-165.666)$ & 0.266 \\
\hline
\end{tabular}

Results are expressed as Median fold change (Interquartile range: 25-75\%)

* significant (Significant level at $P<0.05$ )

\# In-valid P - value because of the small sample size in the groups 
analysis for the combined classifier (miR-210 and miR-1246) resulted in a better sensitivity $(86.36 \%)$ but lower specificity (43.75\%) than either classifier alone.

\section{Discussion}

Previous studies identified miRNAs in several body fluids, including plasma and serum (28), and several members of miRNAs have been proposed as potential biomarkers for several pathological conditions, including human cancer (29-31). One of the advantages that make miRNAs ideal biomarkers is their accessibility and high stability in the circulatory system (32). Several reports have pointed out the diagnostic and prognostic potential of circulating serum miRNAs in different types of cancers (32-37). However, to date, there have been few reports on the role of circulating miRNAs in discriminating metastatic liver tumors from primary HCC tumors. Using the AFP level is known to be of poor sensitivity and specificity to discriminate primary HCC from metastatic liver, where it can be negative in $30-40 \%$ of the primary stages of HCC, in addition, its elevation has also been detected in the presence of acute and chronic viral hepatitis, patients with cirrhosis that is caused by hepatitis as well as with conditions other than the liver, including AFP secreting gastric tumors, colorectal carcinoma, and pancreas (38-40). Moreover, AFP levels may be elevated initially in the early stages of HCC, then drops before rising again as the disease progresses (41). Therefore, this study aimed at investigating the possibility of using some HCC-related miRNAs as noninvasive biomarkers for discriminating primary HCC from metastatic malignancies in the liver, which will be of therapeutic and prognostic significance.

The current study showed that the levels of circulating miR-210 and miR-1246 were statistically different between patients with primary HCC and those with metastatic tumors in the liver. The median fold change of the relative expression level of miR-210 was significantly higher in patients with metastatic liver tumors ( $60 \%$ of cases), compared to patients with primary HCC (30\% of cases). In fact, several studies reported that miR-210, so-called master hypoxamir, is upregulated by hypoxia in most human solid tumors including hepatocellular carcinoma (42-45). Furthermore, Ying et al. (42) showed that the hypoxia-induced miR-210 can promote migration and invasion of HCC cells. miR-210 can be regarded as a (versatile) molecule that regulates cell cycle and affects many aspects of tumor cell in response to hypoxia. It was demonstrated that miR-210 can help tumor cells to adapt the hypoxic stress, through decreasing the mitochondrial function, up-regulating glycolysis, and stimulating angiogenesis (46). The increased level of circulating miR-210 in patients with metastatic tumors in our study, could be due to its increased biogenesis in metastasized tumor tissues and hence, its secretion into circulation. ROC curve analysis showed that miR210 could be used as a marker for patients with metastatic liver tumors from primary HCC patients, with an AUC of 0.67. At the cut-off value of 0.916 , the optimal sensitivity and specificity were $73.68 \%$ and $64.28 \%$, respectively. Recently, Wang et al. (47) have demonstrated that circulating miR-210 can be used as a diagnostic and prognostic biomarker for colorectal cancer. Several previous studies also described an elevated circulating miR-210 in some other cancers, such as pancreatic cancer (37), kidney cancer (48), breast cancer (49), and glioma (50).

In the present study, a higher miR-1246 expression was detected in patients with metastatic liver tumors $(77 \%)$ compared to $45 \%$ in primary HCC. The increased level of circulating miR-1246 in the sera of patients with metastatic tumors is consistent with the findings of Sun et al. (24), who demonstrated that miR-1246 was highly expressed in metastatic HCC cells, and its inhibition effectively reduced migration and invasion of HCC cells, through the down-regulation of its target CADM1. In fact, accumulating evidence from the literature supported the tight link of miR-1246 with several types of tumors. For example, Takeshita et al. (51) have reported that miR-1246 has strong potential as a diagnostic and prognostic biomarker in esophageal squamous cell carcinoma. Further, miR-1246 was recently demonstrated to play an important role in the migration and invasion of non-small lung cancer cells (52) as well as in the metastasis of colorectal cancer (53). The detection of miR-1246 in cancer-derived exosomes has strongly reinforced the potential role of miR-1246 in tumor progression and metastases $(54,55)$. An interesting study has recently reported that colon cancer cells carrying specific mutant $\mathrm{p} 53$ proteins promote the formation of a distinctive population of reprogrammed tumor-associated macrophages by releasing exosomes containing miR-1246 (56). In the present study, ROC curve analysis of miR-1246 for discriminating patients with metastatic liver tumors from primary HCC patients, showed similar results to those obtained for miR-210. Where the AUC was 0.708 , with an optimal sensitivity and specificity of $72.2 \%$ and $67.8 \%$, respectively, at a cut-off value of 9.95 . These findings suggest a relative potential of circulating miR-210 and miR-1246 for discrimination of liver cancer from metastatic origins from those of primary type.

\section{Conclusions}

Our findings suggest that serum miR-210 and miR-1246 have some diagnostic value for discriminating Egyptian patients with metastatic tumors to the livers from patients with primary HCC tumors. The use of these two miRNAs for discrimination would be more effective if combined with a complementary microRNA biomarker for primary HCC tumors, since their expression is more related to metastasis process- 
es. Future studies including large patient populations and patients with metastatic liver tumors of different origins are needed to confirm the potential discriminating value of miR-210 and miR-1246.

Acknowledgments. The authors thank Prof. Dr. Ekram Hamed for his assistance in providing the samples used for this study. This work was completely funded by a grant from Science and Technology Development Fund (STDF), Ministry of Higher Education and Scientific Research, Egypt (Grant No. 1729).

\section{References}

1. El-Garem H, Ammer A, Shehab H, Shaker O, Anwer M, El-Akel W, Omar H. Circulating microRNA, miR-122 and miR-221 signature in Egyptian patients with chronic hepatitis $\mathrm{C}$ related hepatocellular carcinoma. World Journal of Hepatology 2014; 6(11): 818-24.

2. Collinson P. Laboratory medicine is faced with the evolution of medical practice. J Med Biochem 2017; 36: 211-5.

3. Zhu Z, Zhang X, Wang G, Zheng H. Role of MicroRNAs in Hepatocellular Carcinoma. Hepatitis monthly 2014; 14(8): e18672.

4. Milinković $N$, Ignjatović S, Šumarac Z, Majkić-Singh N. Uncertainty of measurement in laboratory medicine. J Med Biochem 2018; 37: 279-88.

5. Pavlidis N, Briasoulis E, Hainsworth J, Greco FA. Diagnostic and therapeutic management of cancer of an unknown primary. European Journal of Cancer 2003; 39(14): 1990-2005

6. Pouessel D, Thezenas S, Culine S, Becht C, Senesse P, Ychou M. Hepatic metastases from carcinomas of unknown primary site. Gastroenterologie clinique et biologique 2005; 29(12): 1224-32.

7. Shaw $\mathrm{PH}$, Adams R, Jordan C, Crosby TD. A clinical review of the investigation and management of carcinoma of unknown primary in a single cancer network. Clinical oncology (Royal College of Radiologists (Great Britain)) 2007; 19(1): 87-95.

8. Giordano S, Columbano A. MicroRNAs: new tools for diagnosis, prognosis, and therapy in hepatocellular carcinoma? Hepatology 2013; 57(2): 840-7.

9. Volinia S, Calin GA, Liu CG, Ambs S, Cimmino A, Petrocca $F$, Visone $R$, lorio $M$, Roldo $C$, Ferracin $M$, Prueitt RL, Yanaihara N, Lanza G, Scarpa A, Vecchione A, Negrini $M$, Harris CC, Croce CM. A microRNA expression signature of human solid tumors defines cancer gene targets. Proceedings of the National Academy of Sciences of the United States of America 2006; 103(7): 2257-61.

10. Rosenfeld N, Aharonov R, Meiri E, Rosenwald S, Spector Y, Zepeniuk M, Benjamin H, Shabes N, Tabak S, Levy A Lebanony D, Goren Y, Silberschein E, Targan N, Ben-Ari A, Gilad S, Sion-Vardy N, Tobar A, Feinmesser M Kharenko O, Nativ O, Nass D, Perelman M, Yosepovich A, Shalmon B, Polak-Charcon S, Fridman E, Avniel A, Bentwich I, Bentwich Z, Cohen D, Chajut A, Barshack I.

\section{Authors' contributions}

The authors declare that each one has contributed equally to every phase of the research and approved the final manuscript.

\section{Conflict of interest statement}

The authors stated that they have no conflicts of interest regarding the publication of this article.

MicroRNAs accurately identify cancer tissue origin. Nature Biotechnology 2008; 26(4): 462-9.

11. Lu J, Getz G, Miska EA, Alvarez-Saavedra E, Lamb J, Peck D, Sweet-Cordero A, Ebert BL, Mak RH, Ferrando AA, Downing JR, Jacks T, Horvitz HR, Golub TR. MicroRNA expression profiles classify human cancers. Nature 2005; 435(7043): 834-8.

12. Cermelli S, Ruggieri A, Marrero JA, loannou GN, Beretta L. Circulating microRNAs in patients with chronic hepatitis $\mathrm{C}$ and non-alcoholic fatty liver disease. PloS one 2011; 6(8): e23937.

13. Chen YP, Jin X, Xiang Z, Chen SH, Li YM. Circulating MicroRNAs as potential biomarkers for alcoholic steatohepatitis. Liver international: official journal of the International Association for the Study of the Liver 2013; 33(8): 1257-65.

14. Chen YJ, Zhu JM, Wu H, Fan J, Zhou J, Hu J, Yu Q, Liu TT, Yang L, Wu CL, Guo XL, Huang XW, Shen XZ. Circulating microRNAs as a Fingerprint for Liver Cirrhosis. PloS one 2013; 8(6): e66577.

15. Tan Y, Ge G, Pan T, Wen D, Chen L, Yu X, Zhou X, Gan J. A serum microRNA panel as potential biomarkers for hepatocellular carcinoma related with hepatitis $B$ virus. PloS one 2014; 9(9): e107986.

16. Wong CM, Wong CC, Lee JM, Fan DN, Au SL, Ng IO Sequential alterations of microRNA expression in hepatocellular carcinoma development and venous metastasis. Hepatology 2012; 55(5): 1453-61.

17. Nass D, Rosenwald S, Meiri E, Gilad S, Tabibian-Keissar $H$, Schlosberg A, Kuker $H$, Sion-Vardy N, Tobar A, Kharenko O, Sitbon E, Lithwick Yanai G, Elyakim E, Cholakh H, Gibori H, Spector Y, Bentwich Z, Barshack I, Rosenfeld N. MiR-92b and miR-9/9* are specifically expressed in brain primary tumors and can be used to differentiate primary from metastatic brain tumors. Brain pathology 2009; 19(3): 375-83.

18. Wu L, Cai C, Wang X, Liu M, Li X, Tang H. MicroRNA142-3p, a new regulator of RAC1, suppresses the migration and invasion of hepatocellular carcinoma cells. FEBS letters 2011; 585(9): 1322-30.

19. Wang J, Li J, Shen J, Wang C, Yang L, Zhang X. MicroRNA-182 downregulates metastasis suppressor 1 and contributes to metastasis of hepatocellular carcinoma. BMC Cancer 2012; 12: 227. 
20. Xiao F, Zhang W, Zhou L, Xie H, Xing C, Ding S, Chen K, Zheng S. MicroRNA-200a is an independent prognostic factor of hepatocellular carcinoma and induces cell cycle arrest by targeting CDK6. Oncology Reports 2013; 30(5): 2203-10.

21. Zhan M, Li Y, Hu B, He X, Huang J, Zhao Y, Fu S, Lu L. Serum microRNA-210 as a predictive biomarker for treatment response and prognosis in patients with hepatocellular carcinoma undergoing transarterial chemoembolization. Journal of vascular and interventional radiology: JVIR 2014; 25(8): 1279-1287 e1.

22. Wang L, Yao J, Shi X, Hu L, Li Z, Song T, Huang C. MicroRNA-302b suppresses cell proliferation by targeting EGFR in human hepatocellular carcinoma SMMC7721 cells. BMC Cancer 2013; 13: 448.

23. Wang G, Sun Y, He Y, Ji C, Hu B, Sun Y. MicroRNA-338$3 p$ inhibits cell proliferation in hepatocellular carcinoma by target forkhead box P4 (FOXP4). International Journal of Clinical and Experimental Pathology 2015; 8(1): 337-44.

24. Sun Z, Meng C, Wang S, Zhou N, Guan M, Bai C, Lu S, Han Q, Zhao RC. MicroRNA-1246 enhances migration and invasion through CADM1 in hepatocellular carcinoma. BMC Cancer 2014; 14: 616.

25. Ali HEA, Abdel Hameed R, Effat $H$, Ahmed EK, Atef AA, Sharawi SK, Ali M, Abd Elmageed ZY, Abdel Wahab AH. Circulating microRNAs panel as a diagnostic tool for discrimination of HCV-associated hepatocellular carcinoma. Clinics and research in hepatology and gastroenterology 2017; 41(4): e51-e62.

26. Erbes T, Hirschfeld $M$, Rucker $G$, Jaeger $M$, Boas J, Iborra S, Mayer S, Gitsch G, Stickeler E. Feasibility of urinary microRNA detection in breast cancer patients and its potential as an innovative non-invasive biomarker. BMC Cancer 2015; 15: 193.

27. Livak KJ, Schmittgen TD. Analysis of relative gene expression data using real-time quantitative PCR and the 2(-Delta Delta C(T)) Method, Methods (San Diego, Calif.) 2001; 25(4): 402-8.

28. Weber JA, Baxter DH, Zhang S, Huang DY, Huang $\mathrm{KH}$, Lee MJ, Galas DJ, Wang K. The microRNA spectrum in 12 body fluids. Clinical Chemistry 2010; 56(11): 173341.

29. Cherradi N. MicroRNAs as Potential Biomarkers in Adrenocortical Cancer: Progress and Challenges. Frontiers in endocrinology 2015; 6: 195.

30. Adachi T, Nakanishi M, Otsuka Y, Nishimura K, Hirokawa G, Goto Y, Nonogi H, Iwai N. Plasma microRNA 499 as a biomarker of acute myocardial infarction. Clinical Chemistry 2010; 56(7): 1183-5.

31. Krauskopf J, Caiment F, Claessen SM, Johnson KJ, Warner RL, Schomaker SJ, Burt DA, Aubrecht J, Kleinjans JC. Application of high-throughput sequencing to circulating microRNAs reveals novel biomarkers for drug-induced liver injury. Toxicological sciences: an official journal of the Society of Toxicology 2015; 143(2) 268-76.

32. Mitchell PS, Parkin RK, Kroh EM, Fritz BR, Wyman SK, Pogosova-Agadjanyan EL, Peterson A, Noteboom J, O'Briant KC, Allen A, Lin DW, Urban N, Drescher CW, Knudsen BS, Stirewalt DL, Gentleman R, Vessella RL,
Nelson PS, Martin DB, Tewari M. Circulating microRNAs as stable blood-based markers for cancer detection. Proceedings of the National Academy of Sciences of the United States of America 2008; 105(30): 10513-8.

33. Luo J, Chen M, Huang $H$, Yuan T, Zhang $M$, Zhang $K$, Deng S. Circulating microRNA-122a as a diagnostic marker for hepatocellular carcinoma. OncoTargets and therapy 2013; 6: 577-83.

34. Chen X, Ba Y, Ma L, Cai X, Yin Y, Wang K, Guo J, Zhang Y, Chen J, Guo X, Li Q, Li X, Wang W, Zhang Y, Wang J, Jiang $X$, Xiang Y, Xu C, Zheng P, Zhang J, Li R, Zhang $H$, Shang X, Gong T, Ning G, Wang J, Zen K, Zhang J, Zhang CY. Characterization of microRNAs in serum: a novel class of biomarkers for diagnosis of cancer and other diseases. Cell Research 2008; 18(10): 997-1006.

35. Taylor DD, Gercel-Taylor C. MicroRNA signatures of tumor-derived exosomes as diagnostic biomarkers of ovarian cancer. Gynecologic Oncology 2008; 110(1): 13-21.

36. Resnick KE, Alder H, Hagan JP, Richardson DL, Croce $C M$, Cohn DE. The detection of differentially expressed microRNAs from the serum of ovarian cancer patients using a novel real-time PCR platform. Gynecologic Oncology 2009; 112(1): 55-9.

37. Ho AS, Huang $X$, Cao $H$, Christman-Skieller C, Bennewith K, Le QT, Koong AC. Circulating miR-210 as a Novel Hypoxia Marker in Pancreatic Cancer. Translational Oncology 2010; 3(2): 109-13.

38. Marx GM, Boyce A, Goldstein D. Elevated alpha-foetoprotein and hepatic metastases - it's not always what it seems!. Annals of Oncology: Official Journal of the European Society for Medical Oncology 2002; 13(1): 167-9.

39. Yachida S, Fukushima N, Nakanishi Y, Akasu T, Kitamura $\mathrm{H}$, Sakamoto M, Shimoda T. Alpha-fetoprotein-producing carcinoma of the colon: report of a case and review of the literature. Diseases of the Colon and Rectum 2003; 46(6): 826-31.

40. Tanno S, Obara T, Fujii T, Izawa T, Mizukami Y, Saitoh Y, Ura H, Kohgo Y. Alpha-Fetoprotein-producing adenocarcinoma of the pancreas presenting focal hepatoid differentiation. International Journal of Pancreatology : Official Journal of the International Association of Pancreatology 1999; 26(1): 43-7.

41. Chen DS, Sung JL, Sheu JC, Lai MY, How SW, Hsu HC, Lee CS, Wei TC. Serum alpha-fetoprotein in the early stage of human hepatocellular carcinoma. Gastroenterology 1984; 86(6): 1404-9.

42. Ying Q, Liang L, Guo W, Zha R, Tian Q, Huang S, Yao J, Ding J, Bao M, Ge C, Yao M, Li J, He X. Hypoxiainducible microRNA-210 augments the metastatic potential of tumor cells by targeting vacuole membrane protein 1 in hepatocellular carcinoma. Hepatology 2011; 54(6): 2064-75.

43. Li L, Huang K, You Y, Fu X, Hu L, Song L, Meng Y. Hypoxia-induced miR-210 in epithelial ovarian cancer enhances cancer cell viability via promoting proliferation and inhibiting apoptosis. International Journal of Oncology 2014; 44(6): 2111-20. 
44. Osugi J, Kimura $Y$, Owada $Y$, Inoue T, Watanabe $Y$, Yamaura T, Fukuhara $M$, Muto $S$, Okabe N, Matsumura $Y$, Hasegawa T, Yonechi A, Hoshino M, Higuchi M, Shio $Y$, Suzuki H, Gotoh M. Prognostic Impact of HypoxiaInducible miRNA-210 in Patients with Lung Adenocarcinoma. Journal of Oncology 2015; 2015: 316745.

45. Samaan S, Khella HW, Girgis A, Scorilas A, Lianidou E, Gabril M, Krylov SN, Jewett M, Bjarnason GA, El-said H, Yousef GM. miR-210 is a prognostic marker in clear cell renal cell carcinoma. The Journal of Molecular Diagnostics: JMD 2015; 17(2): 136-44.

46. Chen Z, Li Y, Zhang H, Huang P, Luthra R. Hypoxia-regulated microRNA-210 modulates mitochondrial function and decreases ISCU and COX10 expression. Oncogene 2010; 29(30): 4362-8.

47. Wang W, Qu A, Liu W, Liu Y, Zheng G, Du L, Zhang X, Yang Y, Wang C, Chen Z. Circulating miR-210 as a diagnostic and prognostic biomarker for colorectal cancer. European Journal of Cancer Care (2016).

48. Iwamoto H, Kanda Y, Sejima T, Osaki M, Okada F, Takenaka A. Serum miR-210 as a potential biomarker of early clear cell renal cell carcinoma. International Journal of Oncology 2014; 44(1): 53-8.

49. Madhavan D, Zucknick M, Wallwiener M, Cuk K, Modugno C, Scharpff M, Schott S, Heil J, Turchinovich A, Yang R, Benner A, Riethdorf S, Trumpp A, Sohn C, Pantel $K$, Schneeweiss A, Burwinkel B. Circulating miRNAs as surrogate markers for circulating tumor cells and prognostic markers in metastatic breast cancer. Clinical cancer research: an official journal of the American Association for Cancer Research 2012; 18(21): 5972-82.

50. Lai NS, Wu DG, Fang XG, LinYC, ChenSS, Li ZB, Xu SS. Serum microRNA-210 as a potential noninvasive bio- marker for the diagnosis and prognosis of glioma. British Journal of Cancer 2015; 112(7): 1241-6.

51. Takeshita N, Hoshino I, Mori M, Akutsu Y, Hanari N, Yoneyama $Y$, Ikeda N, Isozaki Y, Maruyama T, Akanuma N, Komatsu A, Jitsukawa M, Matsubara H. Serum microRNA expression profile: miR-1246 as a novel diagnostic and prognostic biomarker for oesophageal squamous cell carcinoma. British Journal of Cancer 2013; 108(3): 644-52.

52. Kim G, An HJ, Lee MJ, Song JY, Jeong JY, Lee JH, Jeong HC. Hsa-miR-1246 and hsa-miR-1290 are associated with stemness and invasiveness of non-small cell lung cancer. Lung Cancer (Amsterdam, Netherlands) 2016; 91: 15-22.

53. Wang S, Zeng Y, Zhou JM, Nie SL, Peng Q, Gong J, Huo JR. MicroRNA-1246 promotes growth and metastasis of colorectal cancer cells involving CCNG2 reduction. Molecular Medicine Reports 2016; 13(1): 273-80.

54. Neerincx $M$, Sie DL, van de Wiel MA, van Grieken NC, Burggraaf JD, Dekker H, Eijk PP, Ylstra B, Verhoef C, Meijer GA, Buffart TE, Verheul HZM. MiR expression profiles of paired primary colorectal cancer and metastases by next-generation sequencing. Oncogenesis 4 2015; e170.

55. Ogata-Kawata $H$, Izumiya $M$, Kurioka D, Honma $Y$, Yamada Y, Furuta K, Gunji T, Ohta H, Okamoto H, Sonoda H, Watanabe M, Nakagama H, Yokota J, Kohno T, Tsuchiya N. Circulating exosomal microRNAs as biomarkers of colon cancer. PloS one 2014; 9(4): e92921.

56. Cooks T, Pateras IS, Jenkins LM, Patel KM, Robles Al, Morris J, Forshew T, Appella E, Gorgoulis VG, Harris CC. Mutant p53 cancers reprogram macrophages to tumor supporting macrophages via exosomal miR-1246, Nature Communications 2018; 9(1): 771. 